\title{
Nuclear Energy: Non-Electric Applications
}

\author{
Marc A. Rosen ${ }^{1 *}$ \\ ${ }^{1}$ Faculty of Engineering and Applied Science, University of Ontario Institute of Technology, Oshawa, Ontario, L1G 0C5, CANADA
}

*Corresponding Author: marc.rosen@uoit.ca

Citation: Rosen, M. A. (2021). Nuclear Energy: Non-Electric Applications. European Journal of Sustainable Development Research, $5(1)$, em0147. https://doi.org/10.29333/ejosdr/9305

\section{ARTICLE INFO}

Received: 1 Oct. 2020

Accepted: 3 Oct. 2020

\begin{abstract}
Nuclear energy is often viewed as linked exclusively to electrical power generation. However, the applications for nuclear energy are significantly greater than only electricity, and include cogeneration, district heating and cooling, high-temperature process heating, hydrogen and alternative fuel production, transportation and desalination. These additional applications expand the prospects for nuclear energy notably, and enhance the benefits that can be derived from it, such as reduced environmental impact and climate change mitigation. Interest in non-electric applications of nuclear energy is growing for environmental, economic, security and other reasons. In this paper, non-electric applications of nuclear energy are reviewed, including technological, environmental and economic issues of such applications as well as future prospects and benefits of non-electric applications of nuclear energy.
\end{abstract}

Keywords: energy, nuclear energy, non-electric applications, cogeneration, district heating and cooling, desalination

\section{INTRODUCTION}

Nuclear energy is often viewed as and taken to be linked exclusively to power generation. Essentially, this is due to the fact that today nuclear energy is basically a technology for electricity generation. However, the applications for nuclear energy are significantly greater than only electricity. These additional applications expand the prospects for nuclear energy notably, and enhance the benefits that can be derived from it, such as reduced environmental impact and climate change mitigation.

Interest in non-electric applications of nuclear energy is growing for a variety of reasons, some environmental, others economic, and still others related to energy security. As evidence of this interest, it is pointed out that a workshop coorganized by the International Atomic Energy Agency (IAEA) and the Nuclear Energy Agency (NEA) of the Organisation for Economic Co-operation and Development (OECD), was held in Paris in 2013 on assessing the technical and economic factors of non-electric applications of nuclear energy (NUCOGEN, 2013). With participants representing industry, engineering firms, international organizations, research institutions and universities, from nine countries including Canada, Finland, France, Germany, Korea, the Netherlands, Poland, Switzerland, the U.S., the workshop demonstrated the breadth of non-electrical applications of nuclear energy.
The objectives of this paper are to identify and review nonelectric applications of nuclear energy, to describe the technological, environmental and economic issues of such applications, to assess the prospects of non-electric applications of nuclear energy, and to discuss the benefits and advantages that such applications can provide now and in the future.

\section{RECENT ADVANCES AND DEVELOPMENTS RELATING TO NUCLEAR ENERGY IN ENERGY SYSTEMS}

Global, national, regional and local energy systems have been subject to many advances and developments relating to nuclear energy in recent decades, particularly over the ten or so years.

Some of the more common developments, which have occurred in recent years but are also more general, include the following:

- Base-load changes: The roles are changing of base-load electricity generation technologies, such as nuclear power, as the utilization of renewable energy technologies grows and as large-scale energy storage technologies come on line. The intermittency of renewable energy forms such as wind and solar exacerbates this challenge. Further, changes in climate 
due to greenhouse gas emissions are affecting hydraulic energy resources.

- Synergies among energy sources: Synergistic applications of renewable and nuclear energy sources have been developed, demonstrating that increased penetration levels of renewable energy can be attained by advantageously integrating nuclear energy plants with renewable technologies. This integration can offset the requirement for energy storage for renewable energy sources as well as some of their intermittency issues. For instance, Misenheimer and Terry (2017) modeled hybrid nuclear systems with chilled-water storage.

- Low carbon interest: Possible future low carbon electricity systems, including those utilizing renewable and nuclear energy technologies, have been investigated by the NEA. Also, the potential role of nuclear energy in France by 2025 was described, with the share of nuclear power declining to $50 \%$ from its present level of about $75 \%$.

- Fossil fuel concerns: The use of fossil fuels and the corresponding emissions of greenhouse gas emissions have increased for energy systems in most countries. In some jurisdictions, this is attributable to abundant supplies of fossil fuels like natural gas and coal, sometimes due to the inception of new technologies like fracking. At other times, this has been attributable to decreases in fossil fuel prices, often due to occasional supply surpluses combined with challenges in attaining and international agreements on mitigating climate change and pollution and reducing greenhouse gas emissions.

- Safety and health concerns: Concerns related to safety and health affect the public's perception and acceptance of various energy options, especially when the concerns become pronounced. For instance, in the area of nuclear energy technology, public concerns about safety can easily escalate. For instance, the Fukushima Daiichi accident significantly impacted public acceptance of nuclear energy by raising concerns in the public about its safety.

- Economic impacts: Due to global economic crises that occur at intervals, energy consumption at times goes through periods of decline in most countries and funding for energy projects becomes scarcer. The current global pandemic relating to the virus COVID-19 has had such an affect, disrupting most economies of the world.

\section{NUCLEAR ENERGY AT PRESENT}

Nuclear reactors are often operated as base-load electricity generators. In a few countries, so as to provide the capability of managing rapid demand variations, nuclear reactors operate in a load-following mode. This approach can also help manage the intermittent nature of electricity generation from other sources such as some renewable energy forms.
Nuclear power plants produce electricity today that is often competitive in terms of price with other technologies. This is partly due to the fact that nuclear reactors typically have a high availability.

Environmentally, nuclear power plants can be advantageous, as they have little carbon outputs during their operation and over their entire life cycles, so they can contribute significantly to mitigating climate change and other environmental and ecological challenges. For instance, the role of nuclear energy in the reducing pollution has been examined for Pakistan by Mahmood et al. (2020). Much environmental work in this area has focused on climate change, e.g., Saidi and Omri (2020) examine the prospects for nuclear and renewable energy in mitigating carbon dioxide emissions in OECD countries.

Nuclear power is used in many countries, including Canada. Two nuclear power plants in Canada is illustrated in Figures 1 and 2. Shown in Figure 1 is the 3100 MW Pickering Nuclear Generating Station, which over its lifetime has had eight units, and which now provides $14 \%$ of the electricity needs of the province of Ontario, Canada. Shown in Figure 2 is the Darlington Nuclear Generating Station. This four-unit electrical generating station has a total output of $3512 \mathrm{MW}$ and provides about $20 \%$ of the electricity needs of Ontario. Both plants are in Durham Region situated on Lake Ontario, located east of Toronto by $70 \mathrm{~km}$ or less.

\section{NON-ELECTRIC APPLICATIONS OF NUCLEAR ENERGY}

Non-electric applications of nuclear energy are surprisingly broad. They include thermal applications ranging from combined heat and power (CHP) or cogeneration to the provision of heating services at temperatures varying from low to high. In addition, nuclear energy can be used for the production of useful commodities like fresh water via desalination as well as hydrogen and other chemical fuels. Furthermore, non-electric applications of nuclear energy can include energy storage through their synergistic integration with intermittent energy sources. For example, Bragg-Sitton et al. (2020) provided an overview of a program in the United States to maximize energy utilization via integrated nuclearrenewable energy systems, while Rath and Granger Morgan (2020) assess a hybrid system that uses small modular reactors for backing up intermittent renewables and desalinating water.

Non-electric applications of nuclear energy have been considered from a broad viewpoint by several researchers. Ingersoll et al. (2014) examined options for extending nuclear energy to non-electrical applications. Leurent and Cany (2016) provided a comprehensive taxonomy of nuclear non-electric markets and applied it to France. Udalova (2020) took a wider perspective, examining nonpower applications of nuclear technology.

Some applications of nuclear energy for non-electric uses have been understood for decades and, in cases like desalination and district heating, been demonstrated or 


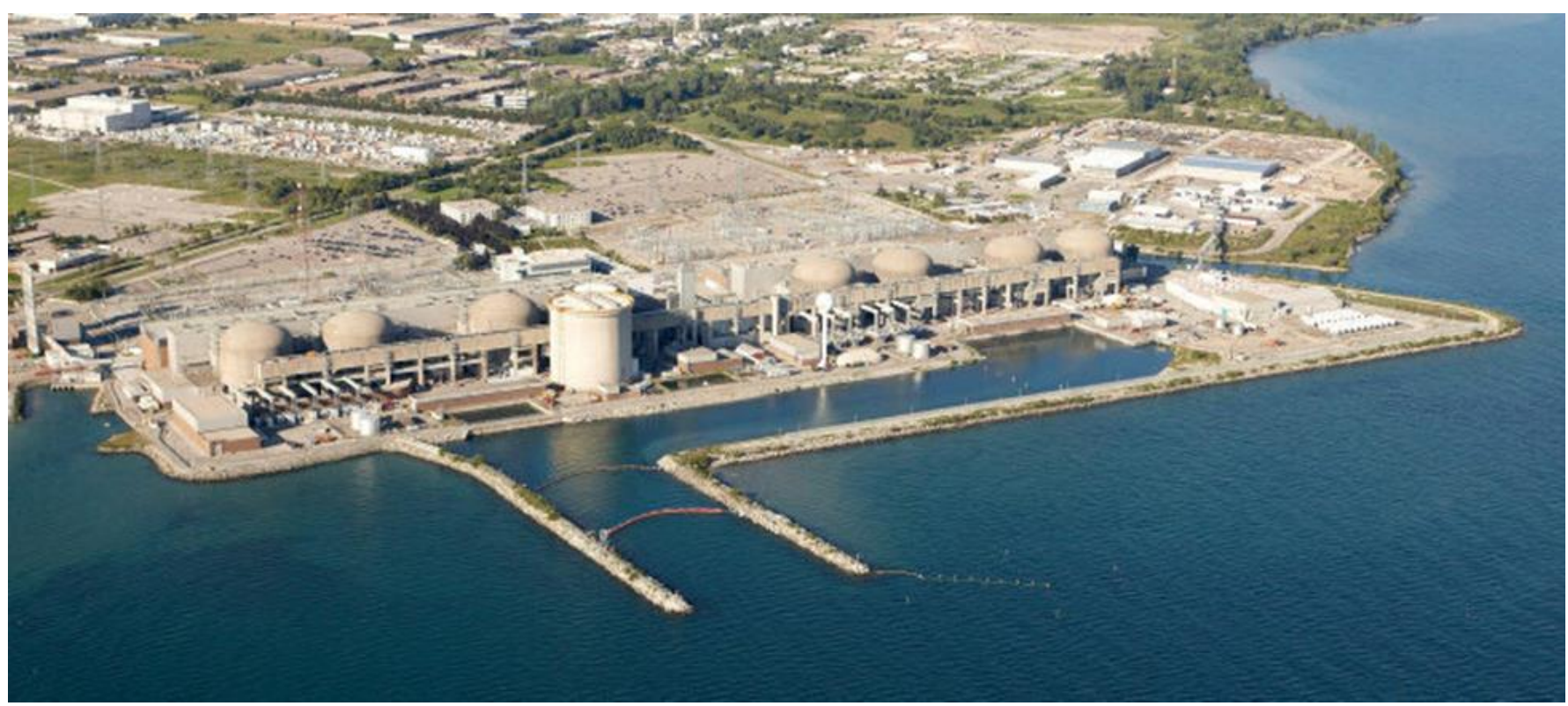

Figure 1. External view of the 3100 MW Pickering Nuclear Generating Station, showing its eight units, in Ontario, Canada. [Copyright (C) Ontario Power Generation Inc., all rights reserved. This information is subject to the general terms of use set out in Ontario Power Generation Inc.'s web site (www.opg.com).]

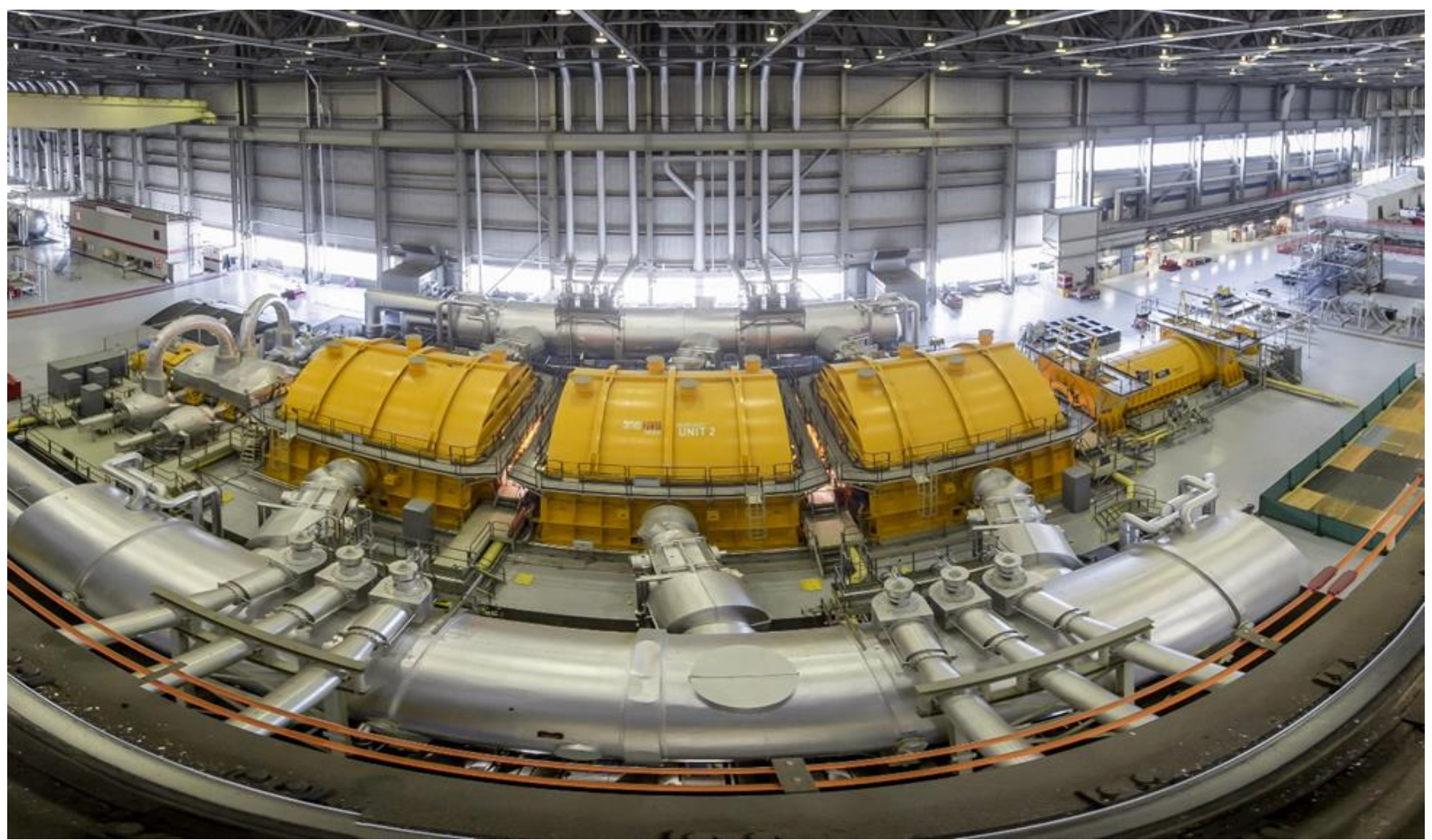

Figure 2. Internal power generation equipment of one unit of the 3512 MW Darlington Nuclear Generating Station, in Ontario, Canada. [Copyright (C) Ontario Power Generation Inc., all rights reserved. This information is subject to the general terms of use set out in Ontario Power Generation Inc.'s web site (www.opg.com).]

implemented industrially. But such applications have been quite limited.

Some of the more significant non-electric applications of nuclear energy are as follows:

- Cogeneration: Nuclear cogeneration applications have a relatively long history, with nuclear cogeneration recording of over 750 reactor-years of experience in non-electric applications (mainly linked to district heating and desalination). The concept of nuclear cogeneration is illustrated in Figure 3. Verfondern and Allelein (2016) investigated the potential of high temperature reactors for cogeneration applications, while Jaskólski et al. (2017) performed thermodynamic and economic analyses of nuclear power unit operating in partial cogeneration mode, in order to produce 


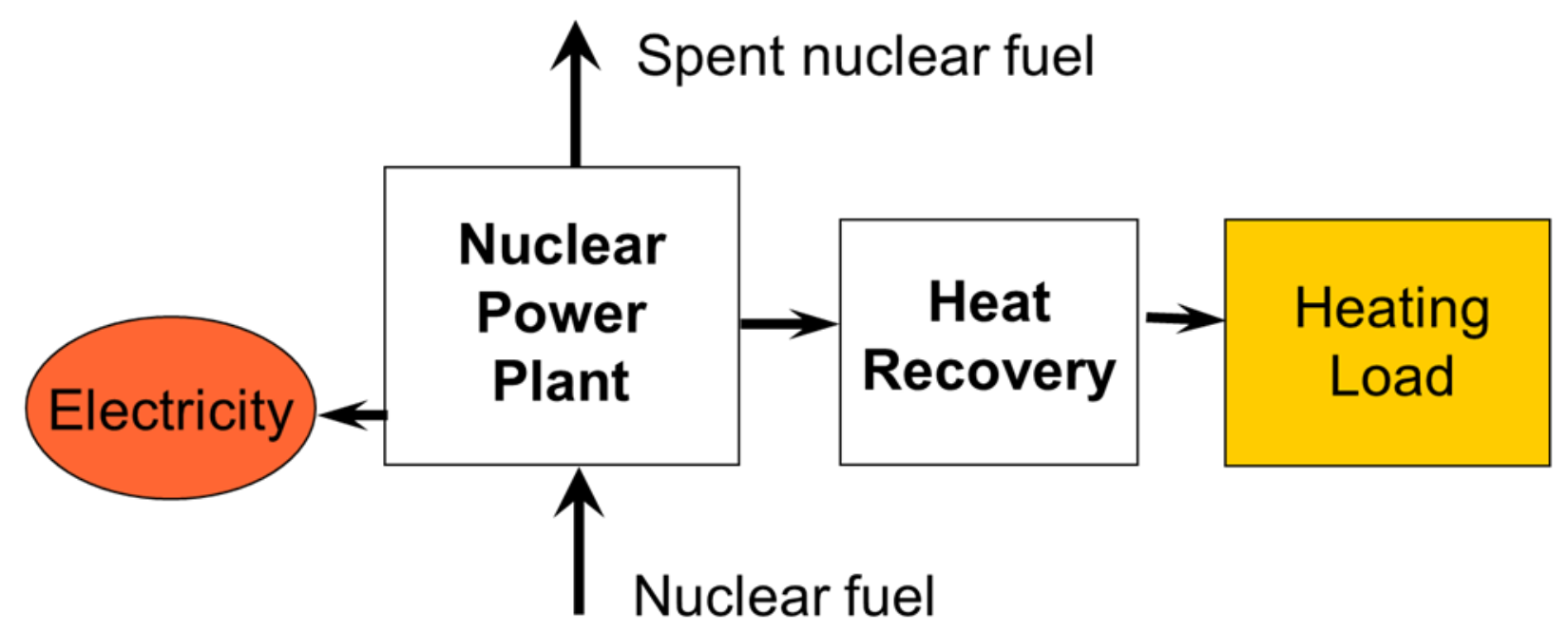

Figure 3. Main steps in the nuclear cogeneration of electricity and heat

electricity and thermal energy suitable for district heating. The European Joint Research Centre has examined cogeneration markets in the European Union along with the competitiveness of nuclear cogeneration in a future energy system. That study also considered challenges such as how to integrate nuclear cogeneration into an energy system. Locatelli et al. (2017) examined the prospects of cogeneration as an option to facilitate load following by small modular reactors. Leurent et al. (2017) described driving forces and obstacles to nuclear cogeneration in Europe, particularly for Finland. Exergy methods have been applied by Dincer and Rosen (2013) to nuclear cogeneration models and economic assessments.

- District heating and cooling: The operation of nuclear district heating and cooling facilities has been documented for several countries, with most focusing on district heating. Others have developed plans for such applications. For instance, Leurent et al. (2018) performed a cost-benefit analysis of district heating systems using heat from nuclear plants in seven European countries. Switzerland and Russia have experience in operating nuclear district heating, in a cogeneration mode. Further, a feasibility study has been carried out in France for district heating using an existing nuclear power plant. Several studies focusing on Finland have been undertaken. A project for nuclear district heating has been proposed, based on the Loviisa nuclear plant in Finland for the metropolitan area of Helsinki, and Värri and Syri (2019) examined the possible role of modular nuclear reactors in district heating for the Helsinki region. Also, Khosravi et al. (2020) investigated the impacts on electricity and district heating markets in Finland of replacing hard coal with wind and nuclear power. Work in this area has also been carried out in other countries. For instance, the status and prospects in China of district heating with a nuclear reactor were investigated by Zhao et al. (2018). More generally, Jaskólski et al. (2017), assessed the provision of district heat via a nuclear power unit operating in partial cogeneration mode.

- High-temperature process heating: High-temperature nuclear heating applications have been used for some time. For instance, nuclear process heating markets have been investigated in the European Union, and process heating applications have been described involving the high temperature gas-cooled reactor (HTGR). Economic facets have been examined of process heat applications in the United States relating to the Next Generation Nuclear Plant (NGNP) project and potential business models for industrial process heat applications have been described. Also, Wang et al. (2020) experimentally studied the performance of a high temperature potassium heat pipe, at various inclination angles and input powers, for nuclear reactor applications, while Qu et al. (2017) examined various thermodynamic schemes involving high temperature gas-cooled reactors.

- Industrial applications: A range of industrial applications of nuclear energy systems has been reported. For instance, Chung et al. (2020) investigated solvent extraction, separation and recovery of thorium from Korean monazite leach liquors for nuclear industry applications. Also, Khalid et al. (2018) investigated the production of hydrogen and copper from copper waste using a thermochemical $\mathrm{Cu}-\mathrm{Cl}$ cycle driven by nuclear energy.

- Hydrogen production: The prospects for hydrogen production from nuclear energy have been examined for decades, and much work on various possible processes has been reported. Correspondingly, economic and cost comparisons of many hydrogen production processes involving nuclear technology have been carried out. Pinsky et al. (2020) comparatively reviewed hydrogen production technologies for nuclear hybrid energy systems, while Petrescu and Petrescu (2019) examined the structure and dimensions of nuclear hydrogen options. A techno- 
economic analysis of load following for small modular reactors for hydrogen and electricity was reported by Locatelli et al. (2018), while Jaszczur et al. (2016) examined the efficiency of producing hydrogen using high temperature nuclear reactors. Environmental studies of nuclear hydrogen production have also been carried out, e.g., Bicer and Dincer (2017) performed a life cycle assessment of nuclear-based hydrogen production. Numerous studies have examined nuclearbased options for hydrogen production via thermochemical water decomposition. For example, analyses have been reported of the integration of the copper-chlorine thermochemical cycle for hydrogen production with a supercritical water-cooled nuclear reactor (Al-Zareer et al., 2017), with a Generation IV lead-cooled nuclear reactor (Al-Zareer et al., 2017), and with a Generation IV gas-cooled fast nuclear reactor (Al-Zareer et al., 2020).

- Alternative fuel production: The production of alternative fuels, other than hydrogen, from nuclear energy have been investigated. The alternative fuels include hydrogen-derived fuels such as methanol and ammonia as well as other fuels. For example, life cycle assessments of nuclear-based ammonia production options have been examined (Bicer and Dincer, 2017).

- Transportation: Nuclear energy has been used or examined for various types of transportation, including land vehicles via fuels such as hydrogen, marine vessels such as ships, and space propulsion systems (World Nuclear Organization, 2020a).

- Desalination: Al-Othman et al. (2019) recently provided a state-of-the-art review of nuclear desalination. Many technical studies have been reported in this area. For example, Khalid et al. (2016) assessed a gas turbinemodular helium reactor for nuclear desalination, while Rath and Granger Morgan (2020) examine a hybrid system using small modular reactors desalinate water, in addition to backing up renewable energy systems. The International Atomic Energy Agency (IAEA) has carried out extensive work on nuclear desalination while the OECD Environment Directorate has carried out research in the area of water resources. In fact, Khamis and El-Emam (2016) describe IAEA coordinated research activity on nuclear desalination, focusing on new technologies and techno-economic assessments. Nuclear desalination is being examined in various jurisdictions. For instance, a fast breeder reactor for electricity and fresh water production has operated in Kazakhstan while the Korean SMART reactor is being considered for desalination markets.

\section{NON-ENERGY APPLICATIONS OF NUCLEAR TECHNOLOGY}

Non-electric applications of nuclear reactors also include non-energy applications (World Nuclear Association, 2020a). Many of these have been utilized or understood for decades, while others are new and in development. Non-energy applications of nuclear technology are beyond the scope of this paper, which focuses on energy applications.

Nevertheless, it is noted that non-energy applications of nuclear technology include the production of radioisotopes and radiation for numerous important applications, some of the most common being (World Nuclear Association, 2020b):

- Medicine and health: Medical uses of nuclear technology are widespread, ranging from diagnostic to therapeutic equipment, and including sterilization of equipment. For example, Shan et al. (2020) study isotopes of medical applications produced in the proton induced reaction on natural cadmium.

- Food and agriculture: Nuclear technology is utilized for improving food preservation and increasing genetic variability. Such technology is also employed for enhancing the sustainability of agriculture, including such activities as improved fertilizer application management and insect control, as well as the conservation and management of existing water supplies and the identification of new ones.

- Industry: Nuclear materials and techniques have been applied to a range of industrial needs. These include industrial and environmental tracers, instrumentation and radiography, as well as the detection and analysis of pollutants (Shan et al., 2020).

- Research: Numerous research applications of nuclear energy exist, including the use of radioisotopes for determining the age of substances through dating.

- Household: Radioisotopes are commonly used today in household smoke detectors.

\section{CHALLENGES AND NEEDS FOR NON- ELECTRIC APPLICATIONS OF NUCLEAR ENERGY}

Present and future challenges relating to developing and implementing non-electric applications of nuclear energy are varied. The development of such applications necessitates that technological and other challenges be overcome.

For instance, a degree of flexibility is needed so as to allow switching between non-electric applications and electricity generation, depending on electricity and other energy commodity prices. This is true whether dealing with current nuclear reactor technology or advanced designs operating at higher temperatures.

Also, further advances and developments in non-electric applications of nuclear energy require solid business cases. In particular, it is necessary to show that such applications are economically competitive with fossil-fuel based technologies or others that can be employed for the same purposes.

Economic requirements to support and enhance nonelectric applications of nuclear energy include the development of a good understanding of energy markets relevant to non-energy applications of nuclear energy and suitable economic approaches and models to assess their costs. Ultimately, the competitiveness of non-energy 
applications of nuclear energy must be demonstrated. Included in this is the need to lower the uncertainties in reactor technology cost assessments, as they affect notably the competitiveness of the non-electric nuclear applications.

Finally, it is also important to increase and improve communications about the merits of non-electric applications of nuclear energy among the numerous stakeholders (e.g., network operators, heat generators, users, municipalities) in such applications.

\section{CONCLUSIONS}

Non-electric applications of nuclear energy are reviewed, including technological, environmental and economic issues of such applications as well as future prospects and benefits of non-electric applications of nuclear energy. The applications for nuclear energy are significantly greater than electricity generation, including cogeneration, district heating and cooling, high-temperature process heating, hydrogen and alternative fuel production, transportation and desalination. These applications of nuclear energy expand its prospects and enhance its benefits, such as reduced environmental impact and climate change mitigation. Interest in non-electric applications of nuclear energy is growing, driven by environmental, economic, security and other reasons. The potential uses of nuclear energy beyond electricity generation and supply are likely to find increasing application in the future.

\section{ACKNOWLEDGEMENTS}

The author is grateful for support provided by the Natural Sciences and Engineering Research Council of Canada, and the contributions of many students over the years who have helped formulate the thoughts presented herein.

\section{REFERENCES}

Al-Othman, A., Darwish, N. N., Qasim, M., Tawalbeh, M., Darwish, N. A. and Hilal, N. (2019). Nuclear desalination: A state-of-the-art review. Desalination, 457, 39-61. https://doi.org/10.1016/j.desal.2019.01.002

Al-Zareer, M., Dincer, I. and Rosen, M. A. (2017). Performance analysis of a supercritical water-cooled nuclear reactor integrated with a combined cycle, a $\mathrm{Cu}-\mathrm{Cl}$ thermochemical cycle and a hydrogen compression system. Applied Energy, 195, 646-658. https://doi.org/10.1016/j.apenergy.2017.03. 046

Al-Zareer, M., Dincer, I. and Rosen, M. A. (2018). Assessment and analysis of hydrogen and electricity production from a Generation IV lead-cooled nuclear reactor integrated with a copper-chlorine thermochemical cycle. International Journal of Energy Research, 42, 91-103. https://doi.org/10.1002/er.3819
Al-Zareer, M., Dincer, I. and Rosen, M. A. (2020). Assessment and analysis of the integrated Generation IV gas-cooled fast nuclear reactor and copper-chlorine cycle for hydrogen and electricity production. Energy Conversion and Management, 205, 112387. https://doi.org/10.1016/ j.enconman.2019.112387

Bicer, Y. and Dincer, I. (2017). Life cycle assessment of nuclear-based hydrogen and ammonia production options: A comparative evaluation. International Journal of Hydrogen Energy, 42(33), 21559-21570. https://doi.org/10.1016/ j.ijhydene.2017.02.002

Bragg - Sitton, S. M., Boardman, R., Rabiti, C. and O’Brien, J. (2020). Reimagining future energy systems: Overview of the US program to maximize energy utilization via integrated nuclear - renewable energy systems. Int J Energy Res, 44(10), 8156-8169. https://doi.org/10.1002/er.5207

Chung, K. W., Yoon, H.-S., Kim, C.-J., Lee, J.-Y. and Kumar Jyothi, R. (2020). Solvent extraction, separation and recovery of thorium from Korean monazite leach liquors for nuclear industry applications. Journal of Industrial and Engineering Chemistry, 83, 72-80. https://doi.org/10.1016/ j.jiec.2019.11.014

Dincer, I. and Rosen, M. A. (2013). Exergy: Energy, Environment and Sustainable Development (2nd ed.), Elsevier, Oxford, UK. https://doi.org/10.1016/B978-0-08-097089-9.00004-8

Ingersoll, D., Houghton, Z., Bromm, R., Desportes, C., McKellar, M. and Boardman, R. (2014). Extending nuclear energy to non-electrical applications. Proceedings of the 19th Pacific Basin Nuclear Conference, Vancouver, B.C., Canada, August 24-28, 2014.

Jaskólski, M., Reński, A. and Minkiewicz, T. (2017). Thermodynamic and economic analysis of nuclear power unit operating in partial cogeneration mode to produce electricity and district heat. Energy, 141, 2470-2483. https://doi.org/10.1016/j.energy.2017.04.144

Jaszczur, M., Rosen, M. A., Sliwa, T., Dudek, M. and Pienkowski, L. (2016). Hydrogen production using high temperature nuclear reactors: Efficiency analysis of a combined cycle. International Journal of Hydrogen Energy, 41(19), 7861-7871. https://doi.org/10.1016/j.ijhydene. 2015.11.190

Khalid, F., Dincer, I. and Rosen, M. A. (2018). Co-production of hydrogen and copper from copper waste using a thermochemical Cu-Cl cycle. Energy \& Fuels, 32, 21372144. https://doi.org/10.1021/acs.energyfuels.7b03857

Khalid, F., Dincer, I., and Rosen, M. A. (2016). Analysis and assessment of a gas turbine-modular helium reactor for nuclear desalination. Journal of Nuclear Engineering and Radiation Science, 2(3), 031014-031014-6. https://doi.org/ 10.1115/1.4032508

Khamis, I. and El-Emam, R. S. (2016). IAEA coordinated research activity on nuclear desalination: the quest for new technologies and techno-economic assessment. Desalination, 394, 56-63. https://doi.org/10.1016/j.desal. 2016.04.015 
Khosravi, A., Olkkonen, V., Farsaei, A. and Syri, S. (2020). Replacing hard coal with wind and nuclear power in Finland: Impacts on electricity and district heating markets. Energy, 203, 117884. https://doi.org/10.1016/ j.energy.2020.117884

Leurent, M. and Cany, C. (2016). A comprehensive taxonomy of nuclear non-electric markets: Application to the market perspectives for France. Proc. 39th Annual Conference of the International Association for Energy Economics (IAEE) on Energy, Expectations and Uncertainties.

Leurent, M., Da Costa, P., Rämä, M., Persson, U. and Jasserand, F. (2018). Cost-benefit analysis of district heating systems using heat from nuclear plants in seven European countries. Energy, 149, 454-472. https://doi.org/10.1016/ j.energy.2018.01.149

Leurent, M., Jasserand, F., Locatelli, G., Palm, J., Rämä, M. and Trianni, A. (2017). Driving forces and obstacles to nuclear cogeneration in Europe: Lessons learnt from Finland. Energy Policy, 107, 138-150. https://doi.org/10.1016/ j.enpol.2017.04.025

Locatelli, G., Boarin, S., Fiordaliso, A. and Ricotti, M. E. (2018). Load following of Small Modular Reactors (SMR) by cogeneration of hydrogen: A techno-economic analysis. Energy, 148, 494-505. https://doi.org/10.1016/j.energy. 2018.01.041

Locatelli, G., Fiordaliso, A., Boarin, S. and Ricotti, M. E. (2017). Cogeneration: An option to facilitate load following in Small Modular Reactors. Progress in Nuclear Energy, 97, 153-161. https://doi.org/10.1016/j.pnucene.2016.12.012

Mahmood, N., Danish, Wang, Z. and Zhang, B. (2020). The role of nuclear energy in the correction of environmental pollution: Evidence from Pakistan. Nuclear Engineering and Technology, 52(6), 1327-1333. https://doi.org/10.1016/ j.net.2019.11.027

Misenheimer, C. T. and Terry, S. D. (2017). Modeling hybrid nuclear systems with chilled-water storage. ASME. J. Energy Resour. Technol., 139(1), 012002. https://doi.org/10.1115/1.4033858

NUCOGEN. (2013). Joint NEA/IAEA Expert Workshop on the Technical and Economic Assessment of Non-Electric Applications of Nuclear Energy, Paris, 4-5 April 2013. Available at: www.oecd-nea.org/ndd/workshops/nucogen (Accessed: 2 July 2020).

Petrescu, F. I. T. and Petrescu, R. V. V. (2019). Nuclear hydrogen structure and dimensions. International Journal of Hydrogen Energy, 44(21), 10833-10837. https://doi.org/10.1016/j.ijhydene.2019.02.140

Pinsky, R., Sabharwall, P., Hartvigsen, J. and O’Brien, J. (2020). Comparative review of hydrogen production technologies for nuclear hybrid energy systems. Progress in Nuclear Energy, 123, 103317. https://doi.org/10.1016/j.pnucene. 2020.103317
Qu, X., Yang, X. and Wang, J. (2017). A study on different thermodynamic cycle schemes coupled with a high temperature gas-cooled reactor. Annals of Nuclear Energy, 106, 185-194. https://doi.org/10.1016/j.anucene.2017.03. 033

Rath, M. and Granger Morgan, M. (2020). Assessment of a hybrid system that uses small modular reactors (SMRs) to back up intermittent renewables and desalinate water. Progress in Nuclear Energy, 122, 103269. https://doi.org/10.1016/j.pnucene.2020.103269

Saidi, K. and Omri, A. (2020). Reducing CO2 emissions in OECD countries: Do renewable and nuclear energy matter? Progress in Nuclear Energy, 126, 103425. https://doi.org/10.1016/j.pnucene.2020.103425

Shan, P. T. M., Musthafa, M. M., Najmunnisa, T., Mohamed Aslam, P., Rajesh, K. K., Hajara, K., Surendran, P., Nair, J. P., Shanbagh, A. and Ghugre, S. S. (2020). Systematic study on some isotopes of medical and industrial applications, produced in proton induced reaction on natural cadmium. Eur. Phys. J. Plus, 135(4), 385. https://doi.org/10.1140/ epjp/s13360-020-00393-w

Udalova, A. A. (2020). Nonpower applications of nuclear technology, Chapter 10. In S. U. Khan and A. Nakhabov (Eds.), Woodhead Publishing Series in Energy, Nuclear Reactor Technology Development and Utilization (pp. 319341). Woodhead Publishing. https://doi.org/10.1016/B9780-12-818483-7.00010-X

Värri, K. and Syri, S. (2019). The possible role of modular nuclear reactors in district heating: Case Helsinki Region. Energies, 12, 2195. https://doi.org/10.3390/en12112195

Verfondern, K. and Allelein, H.-J. (2016). High temperature reactors for cogeneration applications. Kerntechnik, 81(2), 200-203. https://doi.org/10.3139/124.110694

Wang, C., Zhang, L., Liu, X., Tang, S., Qiu, S. and Su, G. H. (2020). Experimental study on startup performance of high temperature potassium heat pipe at different inclination angles and input powers for nuclear reactor application. Annals of Nuclear Energy, 136, 107051. https://doi.org/10.1016/j.anucene.2019.107051

World Nuclear Association, London. (2020a). Non-power Nuclear Applications. Available at: https://www.worldnuclear.org/information-library/non-power-nuclearapplications.aspx (Accessed: 3 July 2020).

World Nuclear Association, London. (2020b). The Many Uses of Nuclear Technology. Available at: https://www.worldnuclear.org/information-library/non-power-nuclearapplications/overview/the-many-uses-of-nucleartechnology.aspx (Accessed: 3 July 2020).

Zhao, J., Xie, F. and Liu, Z. (2018). Status of district heating reactor and its development prospects in China. Proceedings of the 2018 26th International Conference on Nuclear Engineering. London, England. July 22-26, 2018. https://doi.org/10.1115/ICONE26-82445 